\title{
Foreign Direct Investment and Financial Development in Guinea: Causality Analysis
}

\author{
Oumar Keita ${ }^{1}$, Baorong $\mathrm{Yu}^{1} \&$ Nthabeleng Lilian Moshoeshoe ${ }^{1}$ \\ ${ }^{1}$ School of Insurance and Economics, University of International Business and Economics, China \\ Correspondence: Oumar Keita, School of Insurance and Economics, University of International Business and \\ Economics, 10 Huixin Dongjie, Beijing 100029, China. E-mail: oumar.keita2016@yahoo.com
}

Received: October 20, 2021

Accepted: January 7, 2022

Online Published: January 14, 2022

doi:10.5539/ijbm.v17n3p1

URL: https://doi.org/10.5539/ijbm.v17n3p1

\begin{abstract}
This essay provides a better comprehension of the other disregarded impacts of FDI by examining first, the causality direction then the long- and short-term interaction among inward FDI and financial development in Guinea using 1990-2017 data set.

The empirical assertions are grounded on the Granger causality wald test, Bounds test for co-integration, Error correction model (ECM) and the Auto regressive distributed lag (ARDL) framework. FDI per GDP net inflows and Credit to private sector are respectively adopted as FDI measure and financial advancement indicator. The following outcomes are established: first, FDI in the long term negatively influence financial advancement in Guinea at 5\% magnitude. This inference indicates that 1 percent surge in FDI per GDP induces 0.389 decrease in credit to private sector. Second, FDI per GDP [L1] negatively and significantly interact with financial advancement in the short term. Suggesting that 1 percent increase in FDI in the short term engenders 0.215 decrease in credit to private sector. Third, the causality direction remains unidirectional irrespective to the number of lags. Finally, the long- and short-term coefficients tell us the same story regardless of the time effects. Overall, contrary to the common perceptions, we found strong evidence that foreign investment does not enhance financial development in Guinea. In terms of practical implications, it seems ineffective to use FDI as financial advancement instrument within the Guinean context.
\end{abstract}

Keywords: FDI, financial development, economic growth, trade openness, inflation

\section{Introduction}

During the last decades, Foreign Direct Investments have experienced a substantial increase. The global stock in ten years has more than quadrupled to reach a volume of 15 trillion USD in 2013 (UNCTAD, 2014). Over the period 1980-1985, Inward FDI in Africa raised from 41 million USD to 1.06 billion USD over 2003-2007 representing $99 \%$ average growth. Thus, foreign capital has become an essential provenance of outward funds that supplement internal investment, especially for African nations whose current development stage necessitate colossal amount of cash (Seetanah, 2009).

This ever-raising portion of inward foreign capital led scholars to assess the impact of FDI along diverse facets: welfare (Gohou \& Soumaré, 2012); technology transfer (Kim, 2008); employment (Jude \& Silaghi, 2016); competitiveness (Zhang, 2014). Surprisingly, little observation has been paid to the issue of whether foreign investment can enhance or stimulate financial advancement, especially in Guinea.

The subject of financial development is even crucial for Guinea since empirical evidences have displayed that sophisticated financial industry may drive economic advancement and alleviate poverty. Furthermore, some authors posited that nations with well-developed financial system tend to entice additional inward foreign capital, thus achieve more social welfare. However, very few investigations assessed the influence inward FDI may have on financial advancement within the Guinean context.

Despite this lack of attention, there are various theoretical arguments anticipating a direct causal link between inward foreign investment and financial development. First, an augmentation of foreign capital net inflows would generate more economic and productive activities, expand available funds within the recipient country, thus enhance financial intermediation through the banking system or stock markets. Additionally, most of the corporations engaged in transnational investment activities are likely to be registered on local financial market as 
they habitually emanate from advanced economies where stock market financing has become a tradition, particularly for enterprises that are seeking decent reputation among the investment community. Politically, the raise in foreign capital related projects tend to minimize the influence of the elites and persuade them to embrace openness and market liberalization policies, thus boosting the financial industry. Third, foreign investors apprehend an advanced and well-functioning financial industry as a proof of dynamism, vitality, business friendly climate, which encourage them to increase their investment. Additionally, advanced financial industries may ultimately lessen the cost of capital through the increase of liquidity for registered corporations, thus enhancing the attractiveness of the recipient nation. Each of these assertions present a postulatory rationale endorsing a positive interaction among foreign capital and financial advancement.

Within this empirical essay, we scrutinize the causal interaction among inward FDI and financial advancement in Guinea. This assessment seems pertinent for the country, as the local financial system is backward and still experiencing the lack of transparency and low liquidity.

Moreover, the absence of sufficient domestic savings and the deficiency of the financial sector in Guinea have put a damper on the country growth potential. On the one hand, foreign investment flows may induce sectorial reforms and upgrade transparency within the financial industry. On the other hand, advanced financial system can efficiently drive resources into productive activities and generate high returns for foreign investors. We therefore anticipate inward investment and financial development to positively and simultaneously influence each other in the Guinean context.

The rest of the paper is designed as follow: the nexus among inward FDI and financial development is reviewed in section 2 while data and methodology are introduced in section 3 . The outcomes and discussions are exhibited in section 4 whereas conclusions and recommendations are presented in section 5.

\section{Literature Review on FDI and Financial Development Nexus}

The related literature has not presented an inductive theoretical foundation that elucidates the direct interaction among inward investment and financial advancement. However, theoretically the linkage among these two variables was explained from three diverse viewpoints: economic efficiency, allocative channel and liquidity easing.

Proponents of allocative channel assert that advanced financial industry may enhance foreign investment productivity through the optimal allocation of funds towards activities and projects with high return rate (Klein et al. 2000).

On the other hand, economic efficiency rationale advocates that sophisticated stock markets may ease information flows and lessen transaction costs, thus attract more foreign capital inflows (Bartels et al. 2009).

The liquidity easing proponents indicate that advanced financial industry may boost available funds and liquidity in the local economy, thereby enabling swift trading and settlement of financial instruments (Antras et al. 2009).

Empirically, the direct causal association among foreign capital and financial development has not been adequately assessed, singularly in the Guinean context. Otchere et al. (2016) investigated the interaction among FDI and financial advancement in Africa over the period 1990 to 2009. Employing the multivariate method combined with Granger wald test, they inferred a positive interaction and bidirectional linkage among foreign investment and financial advancement in Africa.

Using instrumental variable within two stage least square technique, Agbloyor et al. (2013) exhibit that more inward FDI may promote financial intermediation in Africa. Adopting quarterly data within multivariate co-integration framework in Ghana, Adam and Tweneboah (2009) display a long term and positive interaction among foreign investment and stock market development.

Employing data over 1994-2006 for a panel of 29 developing economies, Soumare and Tchana (2015) assessed the linkage among foreign capital and financial advancement. Their findings showed a bidirectional link among inward FDI and financial market advancement. For the banking system, the outcomes are equivocal and indecisive.

Abdul Malik and Amjad (2013) within the Pakistani context, concluded a long run positive effect of foreign investment on the aggregate stock market advancement.

Desai et al. (2006) using empirical data from United States multinational firms, indicate that removal of restrictions and controls on capital is associated with significant raise in the activities conducted by these corporations via their subsidiaries. Lifting or relaxing control on capital seems promoting rapid growth in multinationals businesses within the recipient nations. From the aforementioned literature, the cost of capital also 
plays a critical role within the interaction among foreign capital and financial advancement since sophisticated financial markets minimize these costs which can entice investments for both domestic firms and foreign subsidiaries.

However, several empirical studies have considered the financial development threshold needed to significantly and positively influence FDI inflows.

Bailliu (2000) assessed the extent to which domestic banking system may enable transnational capital flows to influence economic growth in emerging nations. It was discovered that the ratio commercial banks properties over central bank assets must surpass $58 \%$ in order for foreign capital to spur economic growth. This investigation only focused on the interaction between FDI flows and banking sector excluding the stock and the bond market.

Omran and Bolbol (2003) analyzed the causal linkage among foreign capital and financial advancement within a panel of Arab nations. They also examined the minimal edge of banking system advancement that Arab countries should achieve in order to entice substantial FDI inflows. 0.47 was found to be the required minimal edge ratio (commercial banks properties over central bank assets). The findings also suggest that countries like Yemen, Libya, Sudan and Saudi Arabia whose banking system development threshold was below $47 \%$ were not in a position to enjoy foreign capital induced benefits. On the other hand, nations such as Lebanon, Tunisia and United Arab Emirates (UAE) whose banking system development threshold surpass 0.47 were attracting important amount of FDI inflows.

As policy recommendations, Omran and Bolbol (2003) advocate that inward FDI inducement policies should follow deep domestic financial reforms. Additionally, the regulatory bodies should build up a propitious ecosystem for all stakeholders-local and foreign alike. Governments must strengthen trade liberalization policies as preliminary actions to entice foreign investment. However, the investigation narrowly emphasized on banking system advancement criterion and ignored stock markets index in determining the minimal level of financial industry advancement.

Azman-Saini et al. (2010) empirically assessed the influence of financial markets development on inward FDI using a panel of 91 countries. The study adopted as proxies for financial industry advancement the banking system development measures like the two preceding studies. Authors demonstrated that when bank credit to private sector surpassed a threshold level of $49.7 \%$, substantial foreign capital inflows and their related technological diffusion benefits kicked in. With respect to other financial advancement indexes, $43.1 \%$ and $68.8 \%$ are respectively the minimal threshold in terms of bank credit and liabilities so that foreign investment benefits can be felt in recipient nations.

Selecting a panel of 97 nations across the globe, Dutta and Roy (2011) investigated the causal interaction among foreign investment and financial advancement. FDI per GDP net inflows and the ratio (bank loans to private sector over GDP) were respectively employed as indicators for foreign capital and financial industry advancement. The results displayed that interaction among FDI inflows and banking system development is non-linear. Inward investment positively affects banking system only when private credit to GDP ratio reaches the magnitude of $130 \%$. Moreover, Private credit over GDP ratio exceeding 130\% would negatively influence FDI inflows in the recipient nations. These findings confirmed the remarks from Hailu (2010) who asserted that overly sophisticated financial industry might probably crowd out foreign investment.

As conversed above, the empirical literature related to foreign capital and financial development nexus is relatively abundant and diverse. Some papers explored the causal interaction among the two indicators with assorted outcomes whilst others considered the role financial advancement plays in the relationship among inward investment, economic growth and welfare enhancement. Basically, the majority of these studies found FDI positively correlated with financial advancement particularly in the African context. To our awareness, such empirical examination was not expressly performed in Guinea.

\section{Methodology}

\subsection{Data and Variables Description}

To explore the long- and short-term interactions between inward foreign investment and financial advancement in Guinea, this study essentially adopts the FDI per GDP net inflows and domestic credit to private sector as main indicators. Data are annually time series covering 1990-2017 period. The key variables are collected from World Bank data set. 


\subsubsection{Foreign Direct Investment Variable}

The FDI variable encompasses all kind of inward long and short run capital, reinvested earnings and equity funds. Within this empirical study, per GDP FDI inflows is expected to be a relevant proxy for our analysis.

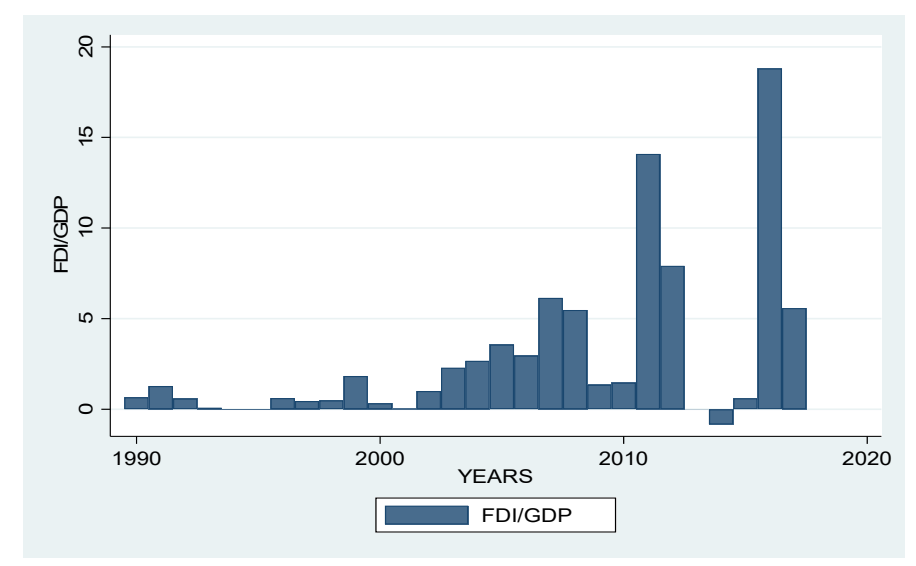

Figure 1. Foreign direct investment per GDP net inflows

\subsubsection{Financial Development Variable}

Several proxies have been recommended in the literature when assessing progress achieved by nations in terms of financial development. Some scholars such Allen et al. (2010) employed the ratio of the total stock market capitalization over GDP to estimate the dimension of the stock market and seize the profoundness of financial industry. Otchere and Senbet (2010) used the stock market turnover ratio which equals the total value of domestic shares traded divided by market capitalization, reflecting the stock market liquidity. Yartey and Adjasi (2007) adopted the total stock market traded value expressed as a percentage of GDP giving insight on the market liquidity.

However, Guinean financial sector as many other African countries still backward, characterized by low liquidity and the inexistence of adequate stock markets. Therefore, financial advancement indicators cited above might not be appropriate within the Guinean context.

For this reason, our empirical analysis considers the "domestic credit to private sector" ratio as the most relevant proxy to capture the progress made in terms of financial intermediation since Guinean financial industry is dominated by commercial banks. It concerns provisions, resources and other types of vehicles (loans) that financial entities propose to private businesses.

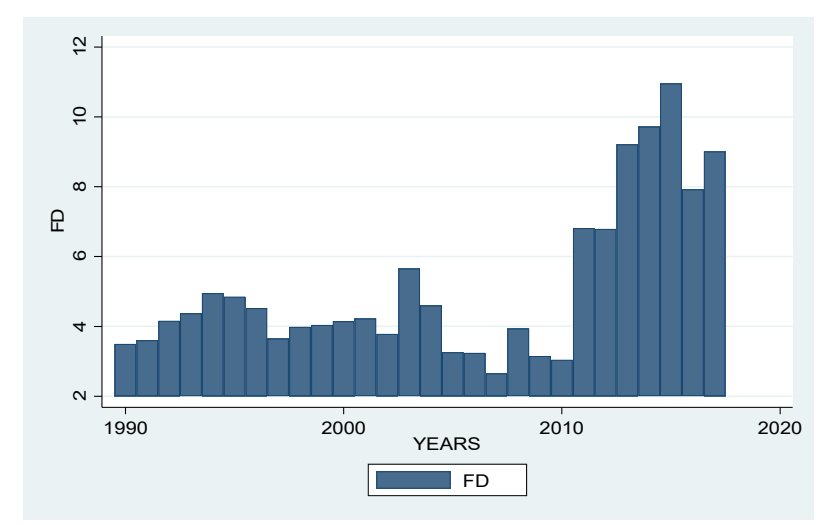

Figure 2. Domestic Credit to Private Sector (\% GDP) 


\subsubsection{Control Variables}

- Trade Openness reveals the extent to which Guinean economy is opened to foreign trade. It's computed as the summation of exports and imports over Gross Domestic Product. This index may also give insight on how friendly Guinea is towards inward foreign investment.

- Inflation variable reflects the average price of a basket of goods and services in Guinean economy over some period of time. It is assumed to be an appropriate proxy for macroeconomic steadiness.

- GDP Growth is the real Gross Domestic Product growth rate. It is commonly adopted when examining the dynamism within Guinean economy. In broad terms, an increase in real GDP is considered as a sign of vitality and healthy economy. Foreign investors perceive it as a huge opportunity and often refer to when choosing their investment destination.

\subsection{Models Specification}

\subsubsection{Causality Direction between FDI and Financial Development Variable}

After checking the stationarity of the variables and conducting the bounds test, we perform Granger causality technique to capture the causality direction among per GDP FDI and Domestic credit to private sector. Since we are employing time series data, Augmented Dickey Fuller sounds to be the appropriate unit root test procedure.

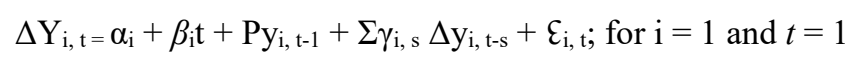

$\mathrm{Y}_{\mathrm{i}, \mathrm{t}}$ is the variable to be tested, $i$ represents the country, $t$ stands for the study period, $\varepsilon_{\mathrm{i}, \mathrm{t}}$ apprehends the normal distribution $N\left(0, \sigma_{\varepsilon}^{2}, \mathrm{j}\right), \alpha_{\mathrm{i}}$ acts as constant and $\beta_{\mathrm{i}} \mathrm{t}$ seizes the time trend.

Next, we conduct Granger wald test among the two main indicators following the standard equation:

$$
\mathrm{Y}_{\mathrm{i}, \mathrm{t}}=\alpha_{\mathrm{i}}+\Sigma \gamma^{\mathrm{k}} \mathrm{y}_{\mathrm{i}, \mathrm{t}-\mathrm{k}}+\Sigma \beta_{\mathrm{i}}^{\mathrm{k}} \mathrm{x}_{\mathrm{i}, \mathrm{t}}+e_{\mathrm{i}, \mathrm{t}}
$$

$x$ and $y$ are both indicators tested stationary, $i$ represents the country and $k$ stands for the time lag.

\subsubsection{Foreign direct investment and Financial Development Nexus}

To assess the long-term impact of foreign capital on financial advancement, the commonly used regression design is:

$$
F i n D e v_{\text {it }}=\beta_{1}+\beta_{2} F D I_{\text {it }}+\beta_{3} X_{\mathrm{it}}+\varepsilon_{\text {it }}
$$

Where FinDev $v_{\text {it }}$ seizes the magnitude of financial advancement for nation $i$ at time $t, F D I_{\text {it }}$ is foreign investment net inflows, $X_{\mathrm{it}}$ represents the control variables while $\varepsilon_{\mathrm{it}}$ embodies the error term. The approximation technique from equation (3) might not enable us to seize the potential adjustment of financial advancement dynamics. For this reason, our empirical investigation scrutinizes the interaction among foreign investment and financial advancement through ECM and ARDL framework specified by Pesaran et al (2001).

$$
\begin{gathered}
\Delta \text { FinDev }_{\mathrm{t}}=\mathrm{a}_{0}+\Sigma_{\mathrm{i}=1}^{\mathrm{p}_{1}} \mathrm{a}_{1 \mathrm{i}} \Delta \text { FinDev }_{\mathrm{t}-\mathrm{i}}+\sum_{\mathrm{i}=1}^{\mathrm{q}_{\mathrm{i}} \mathrm{a}_{2 \mathrm{i}}} \Delta \text { FDI }_{\mathrm{t}-1}+\sum_{\mathrm{i}=1}^{\mathrm{q}_{\mathrm{i}}} \mathrm{a}_{3 \mathrm{i}} \Delta \text { Openness }_{\mathrm{t}-\mathrm{i}}+\sum_{\mathrm{i}=1}^{\mathrm{q}_{\mathrm{i}}} \mathrm{a}_{4 \mathrm{i}} \Delta \text { Inflation }_{\mathrm{t}-1}+\Sigma_{\mathrm{i}=1}^{\mathrm{q}_{1}} \mathrm{a}_{5 \mathrm{i}} \\
\Delta \text { Growth Rate }_{\mathrm{t}-\mathrm{i}}+\lambda \mathrm{ECT}_{\mathrm{t}-1}+\mathrm{e}_{\mathrm{t}}
\end{gathered}
$$

- $\lambda=\left(1-\Sigma^{\mathrm{p}_{\mathrm{i}=1}} \delta_{\mathrm{i}}\right)$, Speed of adjustment parameter with a negative sign

- $\quad \operatorname{ECT}=\left(\Delta\right.$ FinDev $\left._{\mathrm{t}-\mathrm{i}}-\Theta \mathrm{X}_{\mathrm{t}}\right)$, the error correction term is the extracted residuals from the regression of the long-term equation

- $\quad \Theta=\Sigma^{\mathrm{q}_{\mathrm{i}=0}} \beta_{\mathrm{i}} / \alpha$, is the long run parameter

- $a_{1 i}, a_{2 i}, a_{3 i}, a_{4 i}$ and $a_{5 i}$ are the short run dynamic coefficients of the model's adjustment long run equilibrium.

The foregoing approach is remarkable for various motives. Primary, it enables us to overcome the endogeneity bias. Secondly, the ARDL, ECM by Pesaran et al. (2001) can be employed even if the integration order of the time series is different I (0) or I (1) or I (0) and I (1). Third, our empirical framework can simultaneously seize the long- and short-term influences of FDI on financial advancement. 


\section{Empirical Findings}

Table 1. Summary statistics

\begin{tabular}{llllll}
\hline Variables & Obs & Mean & Std. Dev. & Min & Max \\
\hline Credit & 28 & 5.136586 & 2.26786 & 2.6598 & 10.9577 \\
FDI/GDP & 28 & 2.839607 & 4.45062 & -0.84 & 18.81 \\
Growth Rate & 28 & 4.242429 & 2.394725 & -1.118 & 10.829 \\
Inflation & 28 & 12.42286 & 8.882227 & 1.93 & 34.69 \\
Trade Openness & 28 & 64.97464 & 18.29165 & 42.41 & 112.94 \\
\hline
\end{tabular}

Table 2. Pairwise correlation matrix

\begin{tabular}{llllll}
\hline Variables & Credit & FDI/GDP & Growth Rate & Inflation & Trade Openness \\
\hline Credit & 1.0000 & & & & \\
FDI/GDP & 0.2255 & 1.0000 & & & \\
Growth Rate & 0.3736 & 0.5947 & 1.0000 & & \\
Inflation & -0.1945 & 0.2475 & -0.1521 & 1.0000 & \\
Trade Openness & 0.5683 & 0.6815 & 0.5905 & 0.2463 & 1.0000 \\
\hline
\end{tabular}

Table 2 reports the correlation between our variables. The results display that Credit to private sector and GDP growth rate negatively interacted with inflation. These findings are in line with assertions that consider high inflation rate as a distortion factor for financial industry which can put a damper on the country economic growth. On the other hand, FDI per GDP is positively correlated with Credit to private sector agreeing with the predominant theoretical and empirical literature. Overall, the correlation coefficients are less than $75 \%$, endorsing the absence of multi-collinearity among the indicators.

\subsection{Unit Root Test}

Before running the bounds test, ECM and ARDL framework, we adopted Augmented Dickey Fuller procedure to test the integration order of our time series.

$\mathrm{H}_{0}$ (Null hypothesis): the null hypothesis is accepted when the series are stationary at level;

$\mathrm{H}_{1}$ (Alternative hypothesis): the alternative hypothesis is acknowledged when the variables are stationary at first difference.

Table 3. Augmented Dickey Fuller (ADF)

\begin{tabular}{lllll}
\hline Variables & $\begin{array}{l}\text { ADF test } \\
\text { Level }\end{array}$ & First Difference & $\begin{array}{l}\text { PP test } \\
\text { Level }\end{array}$ & First Difference \\
\hline FDI/GDP & $-3.531^{* * *}$ & & $-3.867^{* * *}$ & \\
GDP Growth Rate & -2.594 & $-5.927^{* * *}$ & -2.908 & $-7.453^{* * *}$ \\
Credit to private sector & -0.691 & $-3.914^{* * *}$ & -1.003 & $-6.063^{* * *}$ \\
Inflation & -2.208 & $-3.305^{* * *}$ & -2.636 & $-5.659^{* * *}$ \\
Trade Openness & 0.182 & $-3.282^{* * *}$ & 0.222 & $-5.134^{* * *}$ \\
\hline
\end{tabular}

The Augmented Dickey Fuller unit root test results (table 3) reveal that per GDP FDI inflows is I (0) while trade openness, inflation, Domestic Credit to private sector and GDP Growth rate are I (1). This enables us to perform the Bounds test for co-integration. 
Table 4. Lag selection criteria (1990-2017 sample)

\begin{tabular}{lllllllll}
\hline Lag & LL & LR & df & p & FPE & AIC & HQIC & SBIC \\
\hline 0 & -346.12 & - & - & - & $3.5 \mathrm{e}+06$ & 29.26 & 29.3251 & 29.5054 \\
1 & -285.88 & 120.48 & 25 & 0.000 & 196.426 & 26.3233 & 26.714 & 27.7959 \\
2 & -235.322 & 101.12 & 25 & 0.000 & 319.759 & 24.1935 & 24.9097 & 26.8932 \\
3 & -186.425 & $97.793^{*}$ & 25 & 0.000 & 120.07 & $22.2021^{*}$ & $23.2439^{*}$ & $26.129^{*}$ \\
4 & - & - & 25 & - & $-7.6 \mathrm{e}-26$ & - & - & - \\
\hline
\end{tabular}

Endogenous: Credit to private sector, FDI/GDP, GDP Growth rate, Inflation, trade Openness

Exogenous:_Cons

\begin{tabular}{llllll}
\hline E(lags) [1,5] & Credit & FDI/GDP & Growth rate & Inflation & Openness \\
\hline rl & 3 & 1 & 1 & 2 & 2 \\
\hline
\end{tabular}

4.2 Results of Bounds test for Co-integration

Table 5. Pesaran / Shin / Smith (2001) ARDL Bounds Test:

Ho: No levels relationship

$\mathrm{F}=7.967$

$\mathrm{t}=-5.141$

\begin{tabular}{|c|c|c|c|c|c|c|c|c|}
\hline \multicolumn{9}{|c|}{ Critical Values $(0.1-0.01)$, F-statistic } \\
\hline & \multirow[t]{2}{*}{ [I_0] } & \multirow[t]{2}{*}{ [I_1] } & [I_0] & & [I_0] & & {$\left[\mathrm{I} \_0\right]$} & \multirow[t]{6}{*}{ [I_1] } \\
\hline & & & [I_1] & & [I_1] & & & \\
\hline & L_1 & & L_05 & L_05 & L_025 & L_025 & L_01 & \\
\hline & $L_{-} 1$ & & & & & & L_01 & \\
\hline \multirow[t]{2}{*}{ K_4 } & 2.45 & & 2.86 & & 3.25 & & 3.74 & \\
\hline & 3.52 & & 4.01 & & 4.49 & & 5.06 & \\
\hline \multicolumn{9}{|c|}{ Accept if $\mathrm{F}<$ critical value for I ( 0 ) regressors; Reject if $\mathrm{F}>$ critical value for I ( 1 ) regressors } \\
\hline
\end{tabular}

Accept if $\mathrm{F}<$ critical value for I (0) regressors; Reject if $\mathrm{F}>$ critical value for I (1) regressors

\begin{tabular}{|c|c|c|c|c|c|c|c|c|}
\hline \multicolumn{2}{|c|}{ Critical Values $(0.1-0.01)$} & \multicolumn{7}{|l|}{ t-statistic } \\
\hline & [I_0] & [I_1] & [I_0] & & [I_0] & & [I_0] & [I_1] \\
\hline & & & [I_1] & & [I_1] & & & \\
\hline & L_1 & & L_05 & L_05 & L_025 & L_025 & L_01 & \\
\hline & L_1 & & & & & & L_01 & \\
\hline \multirow[t]{2}{*}{$\mathrm{K} \_4$} & -2.57 & & -2.86 & & -3.13 & & -3.43 & -4.60 \\
\hline & -3.66 & & -3.99 & & -4.26 & & & \\
\hline
\end{tabular}

Accept if $\mathrm{t}>$ critical value for I ( 0 ) regressors; Reject if $\mathrm{t}<$ critical value for I (1) regressors

As the computed F-statistic is greater than the critical value for the upper bound I (1), this finding endorses the existence of co-integration, implying a long run interaction among our variables. Therefore, we can first test the causality direction, then perform the Error correction framework to capture the long- and short-term association between per GDP FDI inflows, Domestic Credit to private sector, trade openness, inflation and GDP Growth rate. 


\subsection{Results of Granger Causality Wald test between Credit to private sector and FDI/GDP}

Table 6a. Credit to private sector and FDI per GDP

\begin{tabular}{llllll}
\hline Equation & Excluded & F & df & df_r & Prob $>$ F \\
\hline Credit & FDI & 3.9168 & 6 & 9 & 0.0332 \\
Credit & ALL & 3.9168 & 6 & 9 & 0.0332 \\
FDI & Credit & 2.4052 & 6 & 9 & 0.1142 \\
FDI & ALL & 2.4052 & 6 & 9 & 0.1142 \\
\hline
\end{tabular}

Table 6b. Credit to private sector and FDI per GDP

\begin{tabular}{llllll}
\hline Equation & Excluded & F & df & df_r & Prob $>$ F \\
\hline Credit & FDI & 5.7057 & 7 & 6 & 0.0249 \\
Credit & ALL & 5.7057 & 7 & 6 & 0.0249 \\
FDI & Credit & 1.8369 & 7 & 6 & 0.2381 \\
FDI & ALL & 1.8369 & 7 & 6 & 0.2381 \\
\hline
\end{tabular}

Table 6 reports the outcomes of the Granger causality Wald test between Credit to private sector and FDI per GDP inflows. It's unlikely to ignore the fact that per GDP FDI granger causes Credit to private sector within the Guinean context. Moreover, irrespective to the number of lags used in the study, the causality among the two variables remains unidirectional. Suggesting the presence of causal linkage among inward investment and financial advancement in Guinea. Furthermore, the bidirectional causality is not endorsed by the findings.

\subsection{Results of Error Correction Model}

Table 7. The long run dynamics

\begin{tabular}{lllllll}
\hline Credit/PS & Coef. & Std. Err. & $\mathrm{t}$ & $\mathrm{P}>[\mathrm{t}]$ & {$[95 \%$ Conf. Interval $]$} & \\
\hline ADJ & & & & & & \\
Credit & & & & & & -0.4403318 \\
L1. & -0.7699514 & 0.14976 & -5.14 & 0.000 & -1.099571 & -0.0797479 \\
LR & & & & & & 1.144758 \\
FDI/GDP & -0.3899016 & 0.140915 & -2.77 & 0.018 & -0.7000553 & 0.0141883 \\
Growth Rate & 0.706479 & 0.199128 & 3.55 & 0.005 & 0.2681994 & 0.2317975 \\
Inflation & -0.0724993 & 0.039385 & -1.84 & 0.093 & -0.1591869 & \\
Openness & 0.1737458 & 0.026375 & 6.59 & 0.000 & 0.115694 & \\
\hline
\end{tabular}

Notes. R-squared $=0.8947 ;$ Adj R-squared $=0.7702$.

The results obtained when performing Error correction technique are reported in table 7. First, The cel. L1 $(-0.7699514)$ which is the speed of adjustment or error correction term towards equilibrium has a negative sign with $1 \%$ significance level, thus we agreed on the existence of long run interaction among per GDP foreign investment, credit to private sector, GDP growth rate, inflation and trade openness.

Overall, foreign direct investment negatively influences financial advancement in Guinea at 5\% magnitude. This outcome indicates that 1 percent rise in FDI per GDP induces 0.389 decrease in credit to private sector. Our finding is contradicting the predominant views about foreign capital in Africa. Those viewpoints argue that African nations by enticing foreign investment can strengthen their financial integration with the rest of the world. The result is even not in line with the evidence from Soumare and Tchana (2015) and Otchere et al. (2016) who endorsed a positive interaction among foreign investment and financial advancement in the long term.

Moreover, GDP growth rate positively interact with credit to private sector at $1 \%$ confidence level meaning that every percent raise in GDP causes 0.706 increase in financial intermediation. This finding agreed with the theoretical argument which posit that GDP growth does generate more economic and productive activities, expand available funds for the local economy which may enhance financial intermediation via the banking 
system or stock markets.

With inflation, the coefficient is negative at $10 \%$ significance level, suggesting that credit to private sector is very sensitive to the macroeconomic environment within the Guinean context.

In the long run, the interaction among trade openness and financial advancement is positive and significant at $1 \%$ magnitude.

Table 8. The short run dynamics

\begin{tabular}{|c|c|c|c|c|c|c|}
\hline Credit & Coef & Std. Err. & $\mathrm{t}$ & $\mathrm{P}>[\mathrm{t}]$ & \multicolumn{2}{|c|}{ [95\% Conf. Interval] } \\
\hline \multicolumn{7}{|l|}{ Credit } \\
\hline L1. & 0.4961535 & 0.1742061 & 2.85 & 0.016 & 0.1127286 & 0.8795785 \\
\hline L2. & 0.0525304 & 0.2541677 & 0.21 & 0.840 & -0.5068891 & 0.6119498 \\
\hline L3. & -0.3186353 & 0.2074101 & -1.54 & 0.153 & -0.7751418 & 0.1378712 \\
\hline \multicolumn{7}{|c|}{ FDI/GDP } \\
\hline-- & -0.0849416 & 0.0906003 & -0.94 & 0.369 & -0.2843515 & 0.1144682 \\
\hline L1. & -0.2152636 & 0.0730989 & -2.94 & 0.013 & -0.3761533 & -0.0543739 \\
\hline \multicolumn{7}{|c|}{ Growth Rate } \\
\hline-- & 0.1341974 & 0.1126702 & 1.19 & 0.259 & -0.1137881 & 0.3821828 \\
\hline L1. & 0.4097571 & 0.1221582 & 3.35 & 0.006 & 0.1408888 & 0.6786254 \\
\hline \multicolumn{7}{|c|}{ Inflation } \\
\hline -- & 0.0556884 & 0.0309365 & 1.80 & 0.099 & -0.0124023 & 0.1237791 \\
\hline L1. & -0.0093618 & 0.0321955 & -0.29 & 0.777 & -0.0802237 & 0.0615001 \\
\hline L2. & -0.1021475 & 0.0316611 & -3.23 & 0.008 & -0.1718332 & -0.0324619 \\
\hline \multicolumn{7}{|c|}{ Openness } \\
\hline-- & -0.0266924 & 0.03271 & -0.82 & 0.432 & -0.0986866 & 0.0453017 \\
\hline L1. & 0.0890522 & 0.03468 & 2.57 & 0.026 & 0.012722 & 0.1653825 \\
\hline L2. & 0.071416 & 0.0351919 & 2.03 & 0.067 & -0.0060408 & 0.1488727 \\
\hline _Cons & -4.913359 & 1.243278 & -3.95 & 0.002 & -7.649795 & -2.176922 \\
\hline
\end{tabular}

Table 8 presents the outcomes of the short-term correlation among FDI, Credit to private sector, GDP growth, inflation and trade openness within the Guinean context. These short run coefficients tell us the same story revealed by the long run analysis.

FDI per GDP and financial advancement variable negatively and significantly influenced each other. Suggesting that 1 percent increase in FDI in the short term causes 0.215 decrease in credit to private sector. With GDP growth, the coefficient is positive at $1 \%$ significance level, meaning that economic growth remains one of the key elements which counts for financial intermediation in Guinea.

The regression coefficient [L2] become negative and significant at $1 \%$ level when inflation interacts with financial development indicator.

Trade openness [L1] and [L2] are positively and significantly associated with credit to private sector ratio, respectively at $5 \%$ and $10 \%$ significance level.

\subsection{Robustness Check}

In order to test the consistency and the reliability of our findings, this empirical paper went through the following diagnostic tests:

Durbin-Watson d-statistic test: $(14,25)=1.971555$

The Durbin-Watson test result (1.971555) definitely deny the existence of serial auto-correlation among the variables.

Table 9. Breusch-Godfrey LM test

\begin{tabular}{llll}
\hline Lags $(\mathrm{p})$ & Chi2 & df & Prob $>$ chi2 \\
\hline 3 & 4.528 & 3 & 0.2098 \\
\hline
\end{tabular}

Ho: no serial correlation 
The Breusch-Godfrey test corroborates the previous finding from Durbin-Watson test. Prob $>$ chi2 $=(0.2098)$ is greater than $5 \%$, rejecting serial auto-correlation bias.

White's test for Ho: Homoskedasticity against Ha: unrestricted heteroskedasticity

$\operatorname{chi} 2(24)=25.00$

Prob $>$ chi $2=0.4058$

The White's test computed outcome Prob $>$ chi2 $=(0.4058)$ is higher than $5 \%$, endorsing the absence of heteroskedasticity among the indicators. Accordingly, our empirical framework is consistent enough.

Table 10. Cameron \& Trivedi's decomposition of IM-test

\begin{tabular}{llll}
\hline Source & Chi2 & df & p \\
\hline Heteroskedasticity & 25.00 & 24 & 0.4058 \\
Skewness & 8.73 & 13 & 0.7931 \\
Kurtosis & 1.08 & 1 & 0.2984 \\
Total & 34.81 & 38 & 0.6178 \\
\hline
\end{tabular}

The skewness and Kurtosis from Cameron \& Trivedi's test [Prob $>$ Chi2 greater than 5\%] confirm that residuals are normally distributed.

\section{Conclusion}

The effect of inward foreign investment on recipient countries has been widely acknowledged while its influence on financial development has not been well approached, especially in the Guinean context. To fill the gap, this empirical research firstly examines the causality direction, then gauges the long- and short-term effect of foreign capital on financial advancement in Guinea over the period 1990-2017. We adopted as FDI measure and financial development indicator, respectively per GDP FDI inflows and the ratio of Credit to private sector (\% GDP).

By applying ECM, the long-term dynamics exhibit that FDI negatively influence financial advancement in Guinea at 5\% magnitude. The outcome also discloses that $1 \%$ surge in FDI per GDP will cause 0.389 decrease in credit to private sector, contradicting the predominant views about foreign capital in Africa which argue that African nations by enticing foreign investment can strengthen their financial integration with the rest of the world. Moreover, GDP growth rate positively interact with credit to private sector at $1 \%$ confidence level while inflation is negatively associated to financial development at $10 \%$ significance level.

In the short term, FDI per GDP [L1] negatively and significantly interacted with financial advancement while GDP growth positively interacts with credit to private sector at $1 \%$ significance level. The regression coefficient [L2] become negative and significant at 1\% magnitude for inflation whereas trade openness [L1] and [L2] positively and significantly interacted with credit to private sector ratio, respectively at $5 \%$ and $10 \%$ significance level.

In summary, this empirical paper observed two main facts about FDI and financial development nexus in Guinea. First, the causality direction between the two variables remains unidirectional irrespective to the number of lags used in the framework. Second, the coefficients of the long- and short-term interactions between foreign investment and credit to private sector tell us the same story regardless of the time effect.

The policy implication from our study is that government should encourage, and direct foreign capital towards sectors that really matter for Guinean economy. The aforementioned contrasting findings may have resulted from the fact that resource seeking FDI remain predominant in Guinea. To tackle this issue, authorities should look at other comparative advantages capable to increase domestic saving which in turn will enhance financial intermediation via the banking system.

\section{References}

Adam, A. M., \& Tweneboah, G. (2009). Foreign Direct Investment and Stock Market Development: Ghana's Evidence. International Research Journal of Finance and Economics, 26, 178-185.

Al Nasser, O. M., \& Soydemir, G. (2010). Domestic and International Determinants of Foreign Direct Investment in Latin America, FMA Annual Meeting. New York, USA.

Alfaro, L., Chanda, A., Kalemli-Ozcan, S., \& Sayek, S. (2004). FDI and Economic Growth: The Role of Local 
Financial Markets. Journal of International Economics, 64(1), 89-112. https://doi.org/10.1016/S0022-1996(03)00081-3

Alfaro, L., Chanda, A., Kalemli-Ozcan, S., \& Sayek, S. (2010). Does Foreign Direct Investment Promote Growth? Exploring the Role of Financial Markets on Linkages. Journal of Development Economics, 91(2), 242-256. https://doi.org/10.1016/j.jdeveco.2009.09.004

Allen, F., Carletti, E., Cull, R., Qian, J., \& Senbet, L. (2010). The African Financial Development Gap. Working Paper, Wharton School, University of Pennsylvania. https://doi.org/10.2139/ssrn.1362216

Allen, F., Otchere, I., \& Senbet, L. (2011). African Financial Systems: A Review. Review of Development Finance, 1, 79-113. https://doi.org/10.1016/j.rdf.2011.03.003

Arellano, M. (2003). Panel Data Econometrics, Oxford University Press. Arellano, M. and S. Bond, 1991, Some Tests of Specification for Panel Data: Monte Carlo Evidence and an Application to Employment Equations. Review of Economic Studies, 58, 277-297. https://doi.org/10.2307/2297968

Arellano, M., \& Bover, O. (1995). Another Look at the Instrumental Variable Estimation of Error-Components Models. Journal of Econometrics, 68(1), 29-51. https://doi.org/10.1016/0304-4076(94)01642-D

Asiedu, E. (2002). On the Determinants of Foreign Direct Investment to Developing Countries: Is Africa Different? World Development, 30(1), 107-119. https://doi.org/10.1016/S0305-750X(01)00100-0

Asiedu, E. (2006). Foreign Direct Investment in Africa: The Role of Natural Resources, Market Size, Government Policy, Institutions and Political Instability. The World Economy, 63-77. https://doi.org/10.1111/j.1467-9701.2006.00758.x

Beck, T., Fuchs, M., \& Uy, M. (2009). Finance in Africa: Achievements and Challenges. World Bank Policy Research Working Paper, 5020. https://doi.org/10.1596/1813-9450-5020

Bekaert, G., Harvey, C. R., \& Lundblad, C. (2005). Does Financial Liberalization Spur Growth? Journal of Financial Economics, 77, 3-56. https://doi.org/10.1016/j.jfineco.2004.05.007

Blundell, R., \& Bond, S. (1998). Initial Conditions and Moment Restrictions in Dynamic Panel Data Models. Journal of Econometrics, 87(1),115-143. https://doi.org/10.1016/S0304-4076(98)00009-8

Carkovic, M., \& Levine, R. (2005). Does Foreign Direct Investment Accelerate Economic Growth? In T. H., Graham, E. M., and M. Blomstrom (Eds.), Does Foreign Direct Investment Promote Development (pp. 195-220). Institute for International Economics, Washington DC.

Choong, C. K. (2012). Does domestic financial development enhance the linkages between foreign direct investment and economic growth? Empirical Economics, 42(3), 819-834. https://doi.org/10.1007/s00181-011-0455-2

Claessens, S., \& Laeven, L. (2003). Financial development, property rights and growth. The Journal of Finance, 8(6), 2401-2435. https://doi.org/10.1046/j.1540-6261.2003.00610.x

Desai, M. A., Foley, C. F., \& Hines Jr., J. R. (2006). Capital Controls, Liberalizations, and Foreign Direct Investment. The Review of Financial Studies, 19, 1434-1464. https://doi.org/10.1093/rfs/hhj041

Dutta, N., \& Roy, S. (2011). Foreign Direct Investment, Financial Development and Political Risks. The Journal of Developing Areas, 44(2), 303-327. https://doi.org/10.1353/jda.0.0106

Ezeoha, A. E., \& Cattaneo, N. (2012). FDI flows to Sub-Saharan Africa: The impact of finance, institution and natural resource endowment. Comparative Economic Studies, 54(3), 597-632. https://doi.org/10.1057/ces.2012.18

Gohou, G. L., \& Soumaré, I. (2011). Does Foreign Direct Investment Reduce Poverty in Africa and Are There Regional Differences? World Development. https://doi.org/10.2139/ssrn.1636352

Guiso, L., Sapienza, P., \& Zingales, L. (2004). Does local financial development matter? The Quarterly Journal of Economics, 119(3), 929-969. https://doi.org/10.1162/0033553041502162

Hailu, Z. A. (2010). Demand side factors affecting the inflow of foreign direct investment to African countries: Does capital market matter? International Journal of Business and Management, 5(5), 103-112. https://doi.org/10.5539/ijbm.v5n5p104

Hair Jr. Black, W. C., Babin, B. J., \& Anderson, R. E. (2014). Multivariate data analysis (7th ed.).

Hansen, B. E. (1999). Threshold effects in non-dynamic panels: Estimation, testing and inference. Journal of 
Econometrics, 93(2), 345-368. https://doi.org/10.1016/S0304-4076(99)00025-1

Havrylchyk, O., \& Poncet, S. (2007). Foreign direct investment in China: Reward or remedy? The World Economy, 30(11), 1662-1681. https://doi.org/10.1111/j.1467-9701.2007.01076.x

Hermes, N., \& Lensink, R. (2003). Foreign direct investment, financial development and economic growth. Journal of Development Studies, 40(1), 142-163. https://doi.org/10.1080/00220380412331293707

Huang, H., \& Xu, C. (1999). Institutions, innovations and growth. American Economic Review, 89(2), 438-443. https://doi.org/10.1257/aer.89.2.438

IMF. (2015). World Economic Outlook: Adjusting to Lower Commodity Prices. Washington (October).

Kaur, M., Yadav, S. S., \& Gautam, V. (2013). Financial system development and foreign direct investment: A panel study for BRICS countries. Global Business Review, 14(4), 729-742. https://doi.org/10.1177/0972150913501607

Kholdy, S., \& Sohrabian, A. (2008). Foreign direct investment, financial markets and political corruption. Journal of Economic Studies, 35(6), 486-500. https://doi.org/10.1108/01443580810916514

Klein, M. W., Peek, J., \& Rosengren, E. (2000). Troubled banks, impaired foreign direct investment: The role of relative access to credit. National Bureau of Economic Research Working Paper Series. Cambridge, 1-34. https://doi.org/10.3386/w7845

Kremer, S., Bick, A., \& Nautz, D. (2013). Inflation and growth: new evidence from a dynamic panel threshold analysis. Empirical Economics, 44(2), 861-878. https://doi.org/10.1007/s00181-012-0553-9

Levine, R. (1997). Stock markets, economic development and capital control liberalization. Perspectives, 3(5), $1-7$.

Ncube, M. (2007). Financial services and economic development in Africa. Journal of African Economies, 16(Supplement 1), 13-57. https://doi.org/10.1093/jae/ejm025

\section{Copyrights}

Copyright for this article is retained by the author(s), with first publication rights granted to the journal.

This is an open-access article distributed under the terms and conditions of the Creative Commons Attribution license (http://creativecommons.org/licenses/by/4.0/). 